\title{
DAMPAK COVID-19 TERHADAP PERUBAHAN HARGA DAN RETURN SAHAM
}

\author{
Novi Darmayanti \\ novismile_ub@yahoo.com \\ Universitas Islam Darul Ulum Lamongan \\ Titik Mildawati \\ Sekolah Tinggi Ilmu Ekonomi Indonesia (STIESIA) Surabaya \\ Fitriah Dwi Susilowati \\ Universitas Airlangga Surabaya
}

\begin{abstract}
COVID-19 is an acronym for "Corona Virus Desease-2019". Emergance at the end of 2019 and the explosion of this virus caused by rapid transmission yo the effects caused and the absence of a vaccine that can definitely fight this virus. In Indonesia, the peak of people's fear of this virus occured when the first COVID-19 case was announced on 2 March 2020. The impact of this outbreak attacked all sectors including the capital market. This study aims to analyze the impact of the announcement on changes in price and stock returns PT. Indosat, Tbk.The analysis technique is the paired sample $T$ test. The results showed that stock prices experienced significant changes with sig.value $0,000<0,05$. While stock returns did not change due the announcement because sig.velue of stock return is 0,946 >0,05. The implication of this research is that PT. Indosat, Tbk. It is hoped that it can strive to maintain the stability of the increase in stock prices in order to maintain investor trust and intereset because a stable stock price value can increase stock returns.
\end{abstract}

Key words: covid-19; capital market; price; return; paired sample t test.

\begin{abstract}
ABSTRAK
Kemunculan COVID-19 di akhir tahun 2019 dan meledaknya virus ini diakibatkan oleh cepatnya penularan hingga dampak yang ditimbulkan serta belum adanya vaksin yang secara pasti dapat melawan virus ini. Di Indonesia, puncak ketakutan masyarakat terhadap virus ini terjadi ketika diumumkannya kasus pertama COVID-19 tanggal 2 Maret 2020. Dampak wabah ini menyerang segala sektor termasuk Pasar Modal. Penelitian ini bertujuan menganalisa dampak pengumuman tersebut terhadap perubahan harga dan return saham PT. Indosat, Tbk. Teknik analisis yang digunakan adalah paired sample $T$ test. Hasil penelitian menunjukkan harga saham mengalami perubahan signifikan dengan nilai sig. 0,000 $<0,05$. Sedangkan return saham tidak mengalami perubahan akibat pengumuman tersebut karena nilai sig. Return saham 0,946 $>0,05$. Implikasi dari penelitian ini adalah PT. Indosat, Tbk. diharapkan dapat berupaya menjaga kestabilan kenaikan harga saham guna menjaga kepercayaan dan ketertarikan investor karena nilai harga saham yang stabil dapat meningkatkan return saham. Harga saham dipengaruhi oleh permintaan dan penawaran atas jasa atau produk yang diperjualbelikan perusahaan, sehingga PT. Indosat dapat memaksimalkan pembelian produk secara online dengan memberi promosi-promosi khusus atas pembelian secara online seperti melalui marketplace dan m-banking.
\end{abstract}

Kata kunci: covid-19; pasar modal; harga; return; uji paired sample t test.

\section{PENDAHULUAN}

Terhitung mulai awal bulan Maret 2020 tepatnya tanggal 2 Maret 2020 kasus per- tama COVID-19 ditemukan di Indonesia. Yakni dua warga Depok seorang ibu dan anaknya yang melakukan kontak fisik 
dengan warga Jepang yang mengunjungi Indonesia dan terkonfirmasi positif korona di Malaysia ketika melakukan transit kembali ke negara asalnya. Sejak saat itu, kasus konfirmasi korona di Indonesia terus bertambah dan meningkat.

Sejak WHO (World Health Organisation) telah menyatakan COVID-19 sebagai darurat kesehatan global, ekonomi dunia telah terpengaruh secara drastis. Penjualan menurun, konsumen mengubah perilaku mereka, produksi berkurang, perusahaan perusahaan berada dalam beban keuangan yang serius, dan tingkat pengangguran yang meningkat di seluruh dunia. Pergeseran drastis dalam bisnis dan ekonomi di seluruh dunia diperkirakan akan mempengaruhi ekuitas serta investasi alternatif seperti pasar mata uang digital. Sampai saat ini, dari perspektif investasi, ada kebutuhan untuk menilai bagaimana pandemi COVID19 mempengaruhi efisiensi dalam cryptoccurrency dan pasar saham (Lahmiri dan Bekiros, 2020).

Dengan adanya wabah COVID-19 ini telah memukul berbagai bidang ekonomi seperti pasar modal. Pandemi virus korona (COVID-19) membawa dampak signifikan terhadap perdagangan di bursa. Hal itu ditunjukkan dengan penurunan Indeks Harga Saham Gabungan (IHSG) di Bursa Efek Indonesia (BEI) (Bursa Efek Indonesia, n.d.). Dalam berita yang dimuat dalam Mediaindonesia.com 28 April 2020 (Nurhidayat, 2020), Direktur Utama BEI, Inarno Djajadi mengungkapkan beberapa di antara penurunan IHSG 26,43\% menjadi 4.635 dengan diikuti penurunan kapitalisasi pasar sebesar 26,35\% menjadi 6.300 triliun, juga terjadi penurunan transaksi harian 1,49\% menjadi 462 ribu kali. Inarno menambahkan penurunan signifikan terhadap perdagangan di bursa juga terdapat pada Maret 2020, saat pemerintah mengumumkan dua kasus positif COVID-19 di Indonesia.

Penurunan dan peningkatan permintaan jasa berbanding lurus dengan rendah tingginya harga saham yang nantinya juga akan berimbas pada penurunan atau peningkatan return saham. Return didefinisikan Halim sebagai imbalan yang diperoleh dari investasi (Seto dan Septianti, 2019).

Fenomena-fenomena yang muncul akhirnya melatarbelakangi peneliti melakukan penelitian yang berjudul Dampak Covid-19 Terhadap Perubahan Harga Dan Return Saham (Studi Kasus Pada Pt Indosat, Tbk.). Berdasarkan latar belakang di atas, maka dapat dirumuskan masalah yaitu apakah terdapat perbedaan signifikan harga saham PT. Indosat, Tbk. sebelum dan sesudah pengumuman nasional kasus pertama COVID-19 dan apakah terdapat perbedaan signifikan return saham PT. Indosat, Tbk. sebelum dan sesudah pengumuman nasional kasus pertama COVID-19?

Tujuan dari penelitian ini adalah menganalisis perbedaan signifikan harga saham PT. Indosat, Tbk. sebelum dan sesudah pengumuman nasional kasus pertama COVID-19 dan menganalisis perbedaan signifikan return saham PT. Indosat, Tbk. sebelum dan sesudah pengumuman nasional kasus pertama COVID-19.

Penelitian ini diharapkan dapat bermanfaat bagi berbagai pihak. Pertama, penelitian ini diharapkan bermanfaat bagi PT. Indosat Tbk dalam membantu menganalisa kinerja saham yang diperjualbelikan di Pasar Modal dengan situasi dan kondisi yang tidak terduga seperti kondisi mewabahnya Pandemi COVID-19 sehingga dapat membuat keputusan yang tepat dan menguntungkan.

Kedua, bagi pihak lain (di luar PT. Indosat Tbk) bisa memberikan pengetahuan mengenai analisa kinerja saham dengan kondisi adanya pandemi COVID-19 (dan sejenisnya) dan memberikan pengetahuan mengenai solusi yang bisa dilakukan agar kinerja saham tetap baik meskipun kondisi pandemi. Ketiga, untuk pengambilan keputusan ekonomi ketiga pimpinan perusahaan atau manajer ketika dalam kondisi covid-19. Keempat, bagi peneliti selanjutnya, penelitian ini diharapkan bisa menjadi referensi dan acuan bagi penelitian 
selanjutnya terutama dalam bidang pasar modal dalam hal harga saham dan return saham. Kelima, penelitian ini diharapkan bisa menjadi sumber referensi bagi pelaku pendidikan tinggi dalam bidang pasar modal dalam hal harga saham dan return saham.

\section{TINJAUAN TEORETIS}

\section{Efficient market theory}

Markowitz (1952) menunjukkan hubungan antara kepercayaan dan pilihan investor dalam konteks pemilihan portofolio yang memiliki ekspektasi atau harapan resiko yang lebih kecil atau minimum. Fama $(1970,1998)$ mendefinisikan pasar efisien adalah pasar yang menyediakan informasi harga saham yang sempurna bagi investor. Dari penjelasan tersebut, bisa disimpulkan bahwa pasar modal yang efisien menjelaskan fenomena adanya pandemic COVID-19, di mana return saham berkorelasi positif dengan resiko sistematik. Artinya bahwa semakin sedikit informasi yang diberikan perusahaan kepada investor terkait dengan return sahamnya, maka investor akan semakin tidak tertarik untuk menanamkan modalnya di perusahaan tersebut. Adanya pandemic COVID-19 ini semakin memperkuat adanya systematic risk, sehingga investor akan bersifat riskaverse (Budiarso et al., 2020).

\section{Prospect theory}

Kahneman dan Tversky (1979) membuktikan bahwa investor akan berperilaku menghindari risiko jika mereka lebih memilih investasi dengan prospek risiko tertentu dalam nilai yang diharapkan tertentu atau fungsi utilitas cekung. Barberis (2013) menegaskan bahwa teori prospek mengandung unsur-unsur seperti ketergantungan referensi, penghindaran kerugian, sensitivitas yang semakin berkurang, dan pembobotan probabilitas. Malkiel (2003) berpendapat bahwa faktor psikologis berperan penting dalam harga pasar. Fama (1970) menyatakan bahwa masalah untuk menguji teori pasar yang efisien adalah bahwa keputusan investasi didasarkan pada asumsi bahwa harga sepenuhnya mencerminkan informasi yang tersedia dan investor menghindari risiko. Teori prospek didasarkan pada investor dan anomali yang menghindari risiko yang menghasilkan hubungan negatif antara risiko dan pengembalian (Beal et al., 2005; Barberis et al., 2016). Fiegenbaum dan Thomas (1988), Shen dan Chih (2005), dan Daniel dan Hirshleifer (2015) juga menegaskan bahwa sesuai dengan teori prospek, investor dengan laba yang lebih tinggi memiliki hubungan yang positif antara risiko dan laba serta menghindari risiko karena target laba berada di atas. tingkat, sedangkan investor dengan laba rendah memiliki hubungan negatif antara risiko dan pengem balian dan merupakan pecinta risiko karena target laba berada di bawah tingkat. Berdasarkan ulasan tersebut, teori prospek sebagai penjelasan atas fenomena pandemi COVID-19 di mana return saham berhubungan negatif dengan risiko sistematis.

\section{Teori Signaling}

Signaling Theory adalah teori yang menjelaskan mengenai sinyal-sinyal yang disampaikan oleh signaler kepada receiver (Connelly et al., 2011). Teori ini pertama kali diperkenalkan oleh Spence pada tahun 1973. Dalam rumusannya tentang teori persinyalan, Spence (1973) memanfaatkan pasar tenaga kerja untuk memodelkan fungsi persinyalan dalam pendidikan. Pemberi kerja potensial kekurangan informasi tentang kualitas calon pekerja. Oleh karena itu, para kandidat memperoleh pendidikan untuk menandai kualitas mereka dan mengurangi asimetri informasi. Ini mungkin merupakan sinyal yang dapat diandalkan karena kandidat berkualitas rendah tidak akan mampu menahan kerasnya pendidikan tinggi.

Menurut Ross (1977), risiko baru-baru ini dipandang sebagai konsekuensi dari kesempurnaan dan persaingan di pasar keuangan. Ross (1977) mendefinisikan sinyal sebagai informasi keuangan yang 
valid oleh perusahaan yang memasuki pasar. Shubiri dan Jamil (2018) menunjukkan bahwa informasi lain di pasar, yang dianggap sebagai risiko yang bersumber dari perusahaan selain risiko sistematis, adalah risiko unsystematic atau risiko idiosinkratik. OuYang et al., (2017) mengemukakan bahwa informasi tentang reaksi saham pada saat krisis oleh media yang memiliki reputasi baik berfungsi sebagai sinyal yang valid bagi investor saat mengevaluasi kualitas perusahaan.

Shubiri dan Jamil (2018) menegaskan bahwa risiko idiosinkratik berkorelasi positif dengan return saham, sedangkan investor memerlukan peningkatan kinerja oleh perusahaan. Liu dan Di Iorio (2016) membuktikan bahwa idiosyncratic risk berkorelasi positif dengan return saham jika investor tidak melakukan diversifikasi portofolionya karena kurangnya informasi. Bozhkov et al., (2018) menegaskan bahwa idiosyncratic risk berkorelasi positif dengan return saham, terutama pada periode resesi. Bouslah et al. (2018) menunjukkan bahwa hubungan negatif antara idiosyncratic risk dan return saham mencerminkan kecenderungan pasar untuk memungkinkan perusahaan meningkatkan kinerjanya selama periode resesi dalam hal mengubah persepsi investor.

Demikian pula, Lee dan Faff (2009) menegaskan bahwa hubungan negatif antara risiko idiosinkratik dan return saham menunjukkan bahwa investor diinformasikan bahwa perusahaan memiliki kinerja keuangan yang lebih baik. Berdasarkan kajian tersebut, teori pensinyalan sebagai penjelasan atas fenomena pandemi Covid19, di mana return saham dikaitkan dengan risiko unsystematic atau idiosyncratic.

Dalam Connelly et al. (2011), menyatakan bahwa terdapat 3 aspek kunci dalam teori signaling yakni pemberi sinyal, penerima sinyal dan sinyal. Gambaran konsep teori signaling terdapat pada gambar 1 .

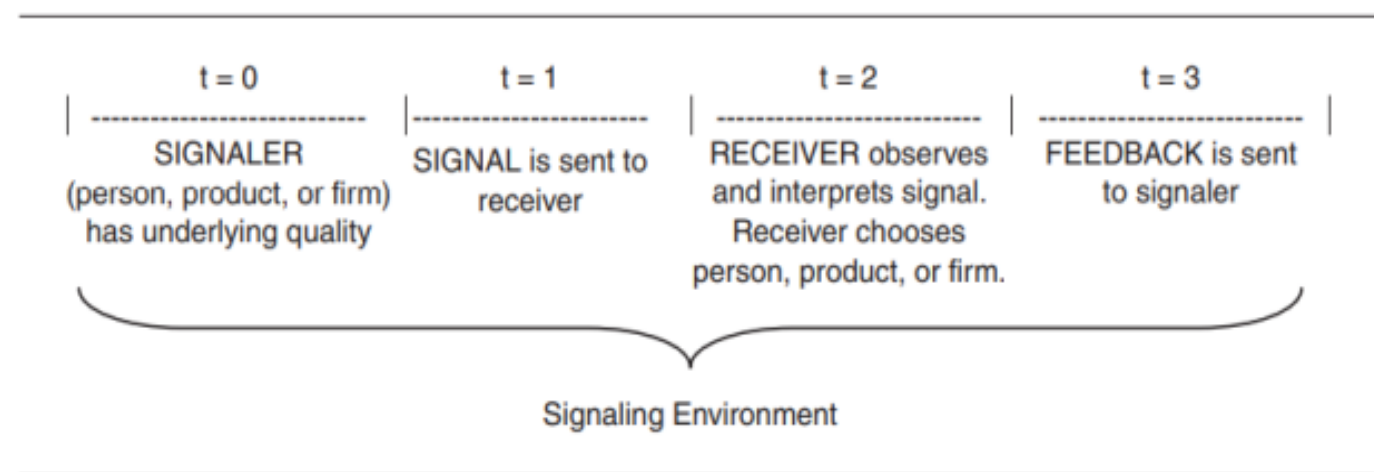

Note: $\mathrm{t}=$ time.

\section{Gambar 1}

Aspek Kunci dalam Signaling

Sumber: Connelly, B. L., Certo, S. T., Ireland, R. D., \& Reutzel, C. R. (2011). Signaling theory: A review and assessment. Journal of management, 37(1), 39-67.

Dalam Gambar 1 juga digambarkan mengenai garis waktu dalam signaling. Garis waktu mencakup tiga aktor utama pemberi sinyal (signaler) dan penerima (receiver)serta sinyal itu sendiri. Gambar ini juga menunjukkan umpan balik yang mungkin untuk pemberi sinyal dan lingkungan pensinyalan, juga beberapa situasi mungkin melibatkan beberapa pemberi sinyal, penerima, atau sinyal. Misalnya, banyak sekali individu (misalnya, investor, pemegang obligasi, dsan lain-lain.) dapat mengamati banyak sinyal, bahkan mungkin bersaing, yang dikirim oleh entitas berbeda dalam suatu perusahaan. Peneliti manajemen telah menemukan bahwa efektivitas pensinyalan sebagian ditentukan oleh karakteristik penerima. Misalnya, proses 
pensinyalan tidak akan berfungsi jika penerima tidak mencari sinyal atau tidak tahu harus mencari apa (Gulati dan Higgins, 2003). Beberapa penerima sinyal (reciever) menafsirkan sinyal secara berbeda dari yang lain (Perkins dan Hendry, 2005). Hal ini juga didukung oleh Branzei et al. (2004) yang menjelaskan bahwa penerima yang berbeda bisa "mengkalibrasi" sinyal atau bahkan arti yang berbeda terhadap suatu sinyal. Dalam lingkungan signaling, baik dalam suatu organisasi atau antar organisasi, juga dipengaruhi oleh sejauh mana pensinyalan (signaling) mengurangi asimetri informasi (Connelly et al., 2010). Distorsi lingkungan terjadi setiap kali media untuk menyebarkan sinyal mengurangi daya observasi sinyal. Contohnya yakni siaran pers atau berita yang berfungsi sebagai sinyal (Carter, 2006). Referensi eksternal juga bisa mengubah hubungan antara pemberi sinyal dan penerima (Branzei et al., 2004).

Menurut Fanni (2012), signaling theory merupakan teori yang menjelaskan bahwa signal-signal yang timbul dari informasi baik yang berasal dari eksternal perusahaan (demo buruh, inflasi bencana alam dan lain-lain) maupun internal perusahaan (kebijakan-kebijakan manajemen) secara langsung akan berpengaruh pada pergerakan harga dari perusahaan terkait. Dalam signaling theory dijelaskan informasi yang dipublikasikan sebagai suatu pengumuman akan memberikan signal bagi investor dalam pengambilan keputusan investasi. Ketika terjadi peristiwa yang mengandung sinyal negatif bagi para investor, maka diperkirakan akan menyebabkan penurunan pada harga saham, volume perdagangan dan abnormal return saham.

Informasi adalah aspek penting bagi seorang investor dan pelaku bisnis karena informasi memberikan keterangan catatan atau gambaran mengenai masa lalu, sekarang maupun masa yang akan datang bagi kelangsungan hidup suatu perusahaan. Informasi yang lengkap, relevan, akurat dan tepat waktu sangat diperlukan oleh investor di pasar modal sebagai alat analisis untuk mengambil keputusan investasi (Arista dan Astohar, 2012). Informasi yang dipublikasikan akan memberikan sinyal bagi investor dalam pengambilan keputusan investasi. Jika pengumuman mengandung nilai yang belum diketahui investor, maka informasi tersebut dianalisis sehingga dapat disimpulkan apakah informasi tersebut memiliki sinyal baik ataukah buruk. Jika informasi memberikan sinyal baik maka diharapkan pasar akan bereaksi pada waktu pengumuman sehingga oleh pasar dan akan terlihat dari adanya perubahan tingkat penjualan saham (Arista dan Astohar, 2012).

\section{Pasar Modal}

Antono et al. (2019) menyatakan investasi memiliki peran penting dalam pembangunan ekonomi bagi negara maju dan negara ekonomi berkembang. Apabila dari tahun ke tahun aktivitas investasi terus mengalami kemunduran, hal itu akan berakibat terhadap pertumbuhan ekonomi karena aktivitas pasar modal merupakan salah satu indikator untuk mengukur perkembangan suatu negara. Berdasarkan Undang-Undang nomor 8 tahun 1995, Pasar Modal adalah kegiatan yang bersangkutan dengan Penawaran Umum dan perdagangan Efek, Perusahaan Publik yang berkaitan dengan Efek yang diterbitkannya, serta lembaga dan profesi yang berkaitan dengan Efek.

Fanni (2012) menjelaskan bahwa Pasar Modal merupakan salah satu instrumen ekonomi. Sehingga pasar modal tidak lepas dari berbagai pengaruh lingkungan yang mencakup faktor ekonomi seperti faktor dalam internal dan eksternal perusahaan, dan non-ekonomi seperti faktor-faktor sosial, politik dan yang mengganggu stabilitas nasional suatu negara.

\section{Saham}

Menurut Kasmir (2014), yang dimaksud saham merupakan surat berharga yang 
bersifat kepemilikan. Investor yang membeli saham memiliki hak kepemilikan atas perusahaan yang menjual sahamnya. Se makin besar saham yang dimilikinya, maka semakin besar kekuasaan yang diperoleh atas perusahaan penjual saham.

Menurut Joshi (2017) keuntungan yang diperoleh atas kepemilikan saham tersebut merupakan hasil dari laba perusahaan yang dibagikan kepada pemegang saham disamping menyisihkan laba ditahan untuk keperluan perusahaan yang lain. Perusahaan yang berkembang pesat seringkali membayar sedikit atau tidak sama sekali, karena sebagian besar pendapatannya disimpan di perusahaan. Di sisi lain, sebuah perusahaan yang sudah mapan atau memiliki riwayat keuntungan yang panjang kemungkinan membayar pengembalian yang relatif tinggi kepada para pemegang sahamnya."

Jenis-jenis saham menurut Jogiyanto (2010) adalah:

1. Saham preferen (preferred stock)

Saham preferen adalah saham yang memiliki hak terlebih dahulu untuk menerima laba dan memiliki hak laba kumulatif. Hak kumulatif merupakan hal mendapatkan laba yang tidak dibagikan pada tahun yang mengalami kerugian tetapi akan dibayarkan pada tahun yang mengalami keuntungan, sehingga saham preferen akan menerima laba sebanyak 2 kali.

2. Saham biasa (Common Stock)

Saham biasa adalah jenis saham yang akan menerima laba setelah laba bagian preferen dibayarkan. Jika perusahaan bangkrut, maka pemegang saham biasa menderita terlebih dahulu karena perhitungan indeks harga saham didasarkan pada saham biasa.

3. Saham Treasury

Saham treasury adalah saham miliki perusahaan yang sudah pernah dikeluarkan dan beredar yang kemudian dibeli lagi oleh perusahaan untuk disimpan sebagai treasuri yang nanti bisa dijual kembali.

\section{Harga Saham}

Prinsip penciptaan kekayaan dalam keuangan sebagian besar didasarkan pada gagasan pembayaran dividen dan kenaikan harga saham (Majanga, 2015). Harga saham mempengaruhi minat investasi karena nilai perusahaan tercermin dalam harga saham. Peningkatan harga saham akan berdampak pada peningkatan minat investor dalam investasi. Peningkatan jumlah investor dimungkinkan untuk mendorong perusahaan tambang melakukan eksplorasi. Investasi publik akan mendorong pertumbuhan ekonomi suatu negara sehingga pemerintah tidak perlu menambah utang negara jika kesadaran investasi publik tinggi (Antono et al., 2019).

Menuru Ikriyah et al. (2017) ada beberapa faktor yang mempengaruhi harga saham seperti:

1. Laba per lembar saham yang diproyeksikan

2. Waktu pernerimaan laba

3. Tingkat resiko usaha

4. Penggunaan utang

5. Kebijakan dividen

6. Faktor eksternal lain

Sedangkan Nurul Ikriyah et al. (2017) juga menjelaskan bahwa terdapat beberapa faktor yang menyebabkan harga saham dapat berfluktuasi, antara lain:

1. Kondisi mikro dan makro ekonomi.

2. Kebijakan perusahaan dalam memutuskan untuk ekspansi (perluasan usaha), seperti membuka kantor cabang (brand office) dan kantor cabang pembantu (subbrand office), baik yang dibuka di domestik maupun luar negeri.

3. Pergantian direksi secara tiba-tiba.

4. Adanya direksi atau pihak komisaris perusahaan yang terlibat tindak pidana dan kasusnya sudah masuk ke pengadilan.

5. Risiko sistematis, yaitu suatu bentuk risiko yang terjadi secara menyeluruh dan telah ikut menyebabkan perusahaan ikut terlibat.

\section{Return Saham}


Return saham merupakan hasil yang diperoleh dari suatu investasi (Arista dan Astohar, 2012). Agung Wibowo dan Susetyo Darmanto (Wibowo dan Darmanto, 2019) menerangkan bahwa "The capital market is very sensitive to various events, both events from internal companies and from external companies. Events from internal companies are micro events that only affect the price volatility and trading activities of the company concerned, while the events from external companies are macro events, which will affect the price volatility and trading activities of companies in all sectors of the capital market......... An event that has a relevant information content for investors will have an impact on price volatility and stock trading activities, thus providing an overview of risk and expedited returns in order to form an optimal portfolio" yang secara singkat dapat dijelaskan bahwa Pasar modal sangat sensitif terhadap berbagai peristiwa, baik peristiwa yang berasal dari dalam maupun dari luar perusahaan. Peristiwa dari dalam perusahaan merupakan peristiwa mikro ekonomi yang dapat mempengaruhi aktivitas harga dan aktivitas perdagangan saham perusahaan yang bersangkutan. Sementara peristiwa dari luar merupakan peristiwa makro ekonomi dimana dampaknya mempengaruhi harga dan aktivitas perdagangan saham perusahaan di semua sektor pasar modal. Peristiwa-peristiwa yang dapat mempengaruhi harga dan aktivitas perdagangan saham perusahaan akan mempengaruhi gambaran risk dan return yang diperoleh oleh investor atas perusahaan.

Menurut Jogiyanto (2010), terdapat 2 jenis return saham yakni return realisasi (realized return) dan return ekspektasi (expected return). Return realisasi adalah return yang dihitung menggunakan data historis. Return ekspektasi adalah return yang diharapkan akan diperoleh oleh para investor di masa mendatang. Return ekspetasi (expected return) dapat dihitung berdasarkan nilai ekspektasian masa depan, berdasarkan nilai-nilai return histori dan berdasarkan model return ekspektasian yang ada.

$$
R_{I}=\frac{P_{1}-P_{0}}{P_{0}}
$$

Dhanya Alex dan Noufal Latheef (2017) menuliskan rumus return saham harian (Daily stock return) sebagai berikut:

$\mathrm{Ri}=$ Return on security $i$.

$\mathrm{P} 1=$ Current day's closing price of security

$\mathrm{P0}=$ Previous day's closing price of security

\section{COVID-19}

Menurut Badar Nadeem Ashraf (2020), COVID-19 merupakan sebuah penyakit menular yang disebabkan coronavirus jenis baru SARS-CoV-2 yang menyebabkan kerusakan di seluruh dunia. Hasibuan et al. (2020), Virus COVID-19 menyebar melalui tetesan atau keluar dari hidung saat orang yang terinfeksi batuk atau bersin, sehingga penting bagi kita untuk mempraktikkan etika pernapasan (seperti batuk pada siku yang tertekuk). Tidak ada obat atau vaksin khusus yang dapat menyembuhkan penyakit ini. Dan sampai saat ini masih dalam penelitian. Orang yang sudah memiliki penyakit bawaan akan memperburuk penyebaran virus ini di tubuhnya.

Mohammad Hidayaturrahman dan Edy Purwanto (2020) mengungkapkan bahwa COVID-19 telah menjadi masalah utama di beberapa negara di dunia. Jumlah kasus korban terpapar berjumlah besar sehingga WHO (World Health Organisation) menetapkan statusnya menjadi pandemi. Banyak kerugian yang dialami oleh negara-negara di dunia akibat pandemi COVID-19, termasuk kerugian dalam bidang ekonomi. Hal ini diperjelas oleh pernyataan Mahammed (2020) bahwa krisis ekonomi karena pandemi ini berbeda dari krisis ekonomi sebelum-sebelumnya, dimana mikrobisnis merupakan bidang yang paling terdampak. Sehingga diperlukan pendorong pada kekuatan ekonomi nasional untuk pemulihan ekonomi pada bisnis kecil atau mikrobisnis, pariwisata, dan makanan. Kemudian, juga dibutuhkan penguatan keuangan seperti sebuah kelonggaran dan kebijakan relaksasi 
keuangan dalam bentuk pembiayaan dan relaksasi kredit untuk usaha pada sektor ekonomi utama dan kecil.

Perbedaan harga saham PT. Indosat, Tbk. sebelum dan sesudah pengumuman nasional kasus pertama COVID-19.

Ikriyah et al. (2017) mengungkapkan bahwa harga saham adalah harga pasar terakhir saat saham tersebut diperjual belikan di pasar modal oleh investor. Harga saham suatu perusahaan pada dasarnya selalu mengalami kenaikan atau penurunan nilai. Hal ini dikarenakan beberapa faktor seperti kondisi makro ekonomi dan faktor eksternal lainnya. COVID-19 yang menjadi wabah penyakit global telah menyerang setiap sektor ekonomi termasuk Pasar Modal. Dalam penelitian Nurmasari (2020) harga saham PT. Ramayana Lestari Sentosa, Tbk. sebelum dan sesudah diumumkannya kasus pertama COVID-19 di Indonesia memperlihatkan perbedaan yang signifikan. Hal tersebut menjadi pembenaran atas pendapat Fanni (2012) yang menyatakan bahwa pasar modal Indonesia semakin sensitif dan bereaksi terhadap peristiwaperistiwa non-ekonomi, yang ditunjukkan dengan adanya perbedaan siginifikan pada harga, abnormal return maupun trading volume activity saham di sekitar tanggal peristiwa. Dimana peristiwa pengumuman COVID-19 merupakan peristiwa non-ekonomi yang ternyata mampu mempengaruhi pasar modal.

Kondisi darurat seperti adanya bencana alam maupun pandemic, seringkali memengaruhi perilaku investor yang akhirnya memengaruhi harga saham (He et al., 2020). Dengan adanya kondisi pandemi COVID-19 memperburuk situasi jika bank gagal memenuhi kebutuhan pembiayaan perusahaan karena terjadi penurunan permintaan tibatiba dan akhirnya berdampak pada jatuhnya pasar saham di seluruh dunia (Khan et al., 2020). Perubahan harga saham saat pandemi bisa terjadi dikarenakan pengeluaran konsumen tertekan lalu perusahaan menurunkan prospek pendapatan mereka yang berdampak pada penilaian ulang pasar terhadap nilai perusahaan dan jatuhnya harga saham yang besar (Mazur et al., 2020). Pasar saham AS, Inggris, Spanyol, Hongkong dan China mengalami penurunan harga saham (Shehzad et al., 2020). Berdasarkan hasil penelitian Salisu dan Akanni (2020) menemukan bahwa pasar saham merespon secara negatif dan luar biasa terhadap pertumbuhan jumlah kasus COVID-19 yang dikonfirmasi.

Kemudian dalam penelitian Seto dan Septianti (2019) yang menyebutkan terdapat perbedaan harga saham PT Garuda Indonesia Tbk sebelum dan sesudah kenaikan harga tiket pesawat. Didukung oleh penelitian yang dilakukan Novitasari et al. (2020) yang menyatakan adanya perbedaan harga saham sebelum dan sesudah stock split. Penelitian-penelitian sebelumnya tersebut merupakan wujud pengaruh peristiwa-peristiwa yang terjadi baik pada perusahaan maupun pasar modal yang dapat mempengaruhi fluktuasi harga saham perusahaan. Berdasarkan penjelasan tersebut, dapat diajukan hipotesis:

$\mathrm{H}_{1}$ : Terdapat perbedaan signifikan harga saham PT. Indosat, Tbk. sebelum dan sesudah pengumuman nasional kasus pertama COVID-19.

Perbedaan return saham PT. Indosat, Tbk. sebelum dan sesudah pengumuman nasional kasus pertama COVID-19.

Arista dan Astohar (2012) menyatakan bahwa return saham merupakan hasil yang diperoleh dari suatu investasi. Hasil yang diperoleh dari suatu investasi dapat berupa keuntungan ataupun kerugian. Hasil yang diperoleh tergantung analisa yang dilakukan oleh investor dalam menilai hasil yang akan diperoleh berdasarkan harga saham yang emiten tawarkan.

COVID-19 yang menjadi wabah penyakit global telah menyerang setiap sektor ekonomi termasuk Pasar Modal diyakini telah mempengaruhi harga saham yang merupakan acuan analisa hasil atau return saham. 
Menurut Ashraf (2020), pasar saham merespons negatif terhadap return pasar saham menurun karena jumlah kasus yang dikonfirmasi meningkat. Pendapat tersebut didukung oleh penelitian Thomas et al. (2020) yang menyimpulkan terjadi dampak negatif pengumuman COVID-19 terhadap NIFTY (Bursa Saham Nasional India). Persitiwa lain seperti pemilu presiden yang merupakan peristiwa politik turut mempengaruhi return saham. Manurung (2019) menyatakan bahwa pemilihan presiden tanggal 17 April 2029 memberikan perubahan terhadap abnormal return saham, abnormal return saham merupakan selisih return saham itu sendiri.

Peristiwa besar dapat secara signifikan mempengaruhi returns pasar saham, terlebih dengan kondisi adanya pandemic COVID-19 di mana virus ini adalah virus baru yang penyebarannya sangat cepat dan belum ada vaksin, sehingga mengakibatkan adanya ketidakpastian yang luarbiasa yang berdampak pada return saham (Al-Awadhi et al., 2020). Kepanikan yang luarbiasa atau ketidakpastian di pasar masing-masing saham yang akhirnya berdampak pada ketidakpastian pada pasar saham dan berdampak pada meningkatkan volatilitas di pasar keuangan sehingga berdampak pada return saham (Apergis dan Apergis, 2020; Salisu dan Akanni, 2020). Hasil penelitian Shehzad et al. (2020) menghasilkan bahwa adanya COVID-19 berpengaruh signifikan terhadap return saham. Berdasarkan penjelasan di atas, maka dapat diusulkan hipotesis:

$\mathrm{H}_{2}$ : Terdapat perbedaan signifikan return saham PT. Indosat, Tbk. sebelum dan sesudah pengumuman nasional kasus pertama COVID-19.

\section{METODE PENELITIAN Jenis Penitian}

Penelitian ini merupakan penelitian dengan pendekatan kuantitatif dengan jenis penelitian Komporatif. Menurut Seto dan Septianti (2019) yang dimaksud jenis penelitian komperatif merupakan penelitian yang memiliki tujuan mencari tahu dan membandingkan. Dalam penelitian ini penelitian dilakukan dengan tujuan mencari tahu dan membandingkan harga saham dan return saham PT. Indosat, Tbk sebelum dan sesudah pengumuman nasional COVID-19 di Indonesia untuk pertama kali yakni pada tanggal 02 Maret 2020. Penelitian ini dilakukan dengan mencari data melalui internet yaitu dengan memanfaatkan situs idx. co.id atau dengan mendatangi kantor galeri Bursa Efek Indonesia yang terletak di kompleks Universitas Muhammadyah Gresik atau Bursa Efek Indonesia di Surabaya.

\section{Obyek Penelitian}

Obyek Penelitian merupakan pusat perhatian dalam penelitian. Obyek penelitian yang akan diteliti dalam penelitian ini adalah perbedaan signifikan harga dan return saham PT. Indosat, Tbk. sebelum dan sesudah pengumuman nasional kasus pertama COVID-19.

\section{Variabel Penelitian}

Sugiyono, 2019:67) menjelaskan secara teoritis variabel disebut sebagai atribut seseorang, atau obyek yang mempunyai variasi antara orang atau obyek dengan yang lainnya. Variabel dalam penelitian ini dapat dijelaskan sebagai berikut:

1. Data sebelum pengumuman nasional kasus covid-19 di Indonesia untuk pertama kali $\left(\mathrm{X}_{1}\right)$. Data sebelum pegumuman nasional kasus covid-19 di Indonesia untuk pertama kali ini meliputi data harga dan return saham PT. Indosat, Tbk. Pada penelitian ini, data yang diambil sebelum kasus pertama virus corona sebanyak 24.

2. Data sesudah pengumuman nasional kasus covid-19 di Indonesia untuk pertama kali $\left(\mathrm{X}_{2}\right)$. Data sesudah pengumuman nasional kasus covid-19 di Indonesia untuk pertama kali ini meliputi data harga dan return saham PT. Indosat, Tbk. Pada penelitian ini, data yang diambil sesudah kasus pertama covid-19 sebanyak 31 . 


\section{Teknik Pengumpulan Data}

Jenis dan Sumber Data Data yang digunakan merupakan data sekunder. Pengumpulan data dilakukan dengan meminta data kepada Bursa Efek Indonesia atau melalui internet idx.co.id dan membaca buku untuk mendapatkan teori yang berkaitan dengan penelitian. Instrumen penelitian yang digunakan dalam penelitian ini adalah dokumentasi dengan cara melihat, mempelajari, dan menganalisis informasi yang diperoleh dari Bursa Efek Indonesia terkait harga dan return saham milik PT. Indosat Tbk dengan closing price harian mulai tanggal Januari 2020 sampai April 2020.

\section{Metode Analisis Data}

Menurut Ikriyah et al. (2017), analisis data adalah proses mengorganisasikan dan mengurutkan data kedalam pola, kategori, dan satuan uraian dasar sehingga dapat ditemukan tema dan tempat dirumuskan hipotesis kerja seperti yang disarankan oleh data. Untuk menganalisis diutamakan pada uji normalitas data, apabila data berdistribusi normal maka uji yang digunakan adalah uji parametrik Paired Sample t Test, namun apabila data tidak berdistribusi normal maka uji yang digunakan adalah uji nonparametrik Wilcoxon Signed Ranks Test. Untuk mempermudah dalam menganalisis digunakan software SPSS (Statistical Package for Social Science).

Tahapan Uji yang dilakukan adalah:

1. Uji Statistik Deskriptif

Statistik deskriptif digunakan untuk memberikan gambaran maupun deskripsi mengenai nilai rata-rata, standar deviasi, nilai maksimum, dan nilai minimum untuk data kuantitatif sedangkan data kualitatif menggunakan distribusi frekuensi (Ikriyah et al., 2017).

2. Uji Normalitas

Uji Normalitas bertujuan untuk menguji apakah dalam sebuah model regresi, variabel dependen, variabel independen, atau keduanya mempunyai distribusi normal atau tidak (Seto dan Septianti, 2019). Uji normalitas yang akan digunakan merupakan Uji Normalitas Shapiro Wilk, hal ini dilakukan karena data sampel kurang dari 50 .

3. Uji Hipotesis

Menurut Novitasari et al. (2020), Paired Sample T Test digunakan jika data berdistribusi normal. Sedangkan untuk data tidak berdistribusi normal menggunakan uji nonparametrik Wilcoxon Signed Ranks Test.

\section{Definisi Operasional Variabel}

Definisi operasional dari variabel penelitian yang digunakan pada penelitian ini dapat dilihat pada Tabel berikut ini:

Tabel 1

Pengukuran Variabel

\begin{tabular}{|c|c|c|c|c|}
\hline Jenis Variabel & Definisi Operasional & Skala & Indikator & Sumber \\
\hline Harga Saham & $\begin{array}{l}\text { Harga saham adalah harga } \\
\text { pasar terakhir saat saham } \\
\text { tersebut diperjualbelikan di } \\
\text { pasar modal oleh investor. }\end{array}$ & Nominal & $\begin{array}{l}\text { Harga Saham } \\
\text { penutupan } \\
\text { harian }\end{array}$ & $\begin{array}{c}\text { Ikriyah et al., } \\
\text { (2017:66) }\end{array}$ \\
\hline Return Saham & $\begin{array}{l}\text { Return saham merupakan } \\
\text { hasil pengurangan harga } \\
\text { saham suatu periode } \\
\text { dengan harga saham } \\
\text { periode sebelumnya dan } \\
\text { dibagi dengan harga } \\
\text { saham periode } \\
\text { sebelumnya. }\end{array}$ & Rasio & $\begin{array}{l}\text { Return saham = } \\
(\mathrm{P} 1-\mathrm{P} 0) / \mathrm{P} 0\end{array}$ & $\begin{array}{l}\text { Brigham dan } \\
\text { Houston (2011) }\end{array}$ \\
\hline
\end{tabular}


ANALISIS DAN PEMBAHASAN

Hasil Penelitian

Tabel 2

Uji Statistik Deskriptif Return Saham

\begin{tabular}{lrrrrr}
\hline & N & Minimum & Maximum & Mean & $\begin{array}{c}\text { Std. } \\
\text { Deviation }\end{array}$ \\
\hline Sebelum & 23 & $-0,09$ & 0,10 & $-0,0037$ & 0,04332 \\
Sesudah & 23 & $-0,09$ & 0,12 & $-0,0049$ & 0,06753 \\
Valid N (listwise) & 23 & & & & \\
\hline Sumber :Data diolah dengan SPSS 25 (2020) & & & &
\end{tabular}

\section{Hasil Uji Statistik Deskriptif}

Hasil Uji Deskriptif yang diolah peneliti menunjukkan nilai rata-rata (mean) return saham sebelum pengumuman kasus COVID-19 di Indonesia untuk pertama kali (Sebelum) sebesar -0,0037 dengan standar devisiasi 0,04332. Kemudian nilai minimum sebesar $-0,09$ dan nilai maksimum return saham sebesar 0,10 selama 23 hari hari kerja pasar modal sebelum pengumuman. Sedangkan Uji Deskriptif yang diolah peneliti menunjukkan nilai rata-rata (mean) return saham sesudah pengumuman kasus COVID-19 di Indonesia untuk pertama kali (Sesudah) sebesar -0,0049 dengan standar devisiasi 0,06753.

Hasil Uji Normalitas Harga Saham
Kemudian nilai minimum sebesar $-0,09$ dan nilai maksimum return saham sebesar $R p$. 0,12 selama 23 hari hari kerja pasar modal sesudah pengumuman. Data yang ditunjukkan pada tabel 2 terlihat bahwa nilai mean dari return saham juga telah mengalami kemerosotan setelah pengumuman petama kali kasus COVID-19 di Indonesia.

Sebelum pengumuman nilai mean adalah -0,0037 dan kemudian setelah dilakukannya pengumuman kasus COVID-19 untuk pertama kali di Indonesia nilai mean return saham lebih rendah menjadi -0,0049. Hal ini dapat terjadi diakibatkan penurunan harga saham perusahaan.

Tabel 3

Uji Normalitas Harga Saham

\begin{tabular}{lllllll}
\hline & $\begin{array}{l}\text { Kolmogorov- } \\
\text { Smirnov }^{\mathbf{a}}\end{array}$ & & \multicolumn{3}{c}{$\begin{array}{l}\text { Shapiro- } \\
\text { Wilk }\end{array}$} \\
\hline Sebelum & Statistic & Df & Sig. & Statistic & Df & Sig. \\
Sesudah & 0,112 & 24 &, $200^{*}$ & 0,967 & 24 & 0,592 \\
& 0,136 & 24 &, $200^{*}$ & 0,922 & 24 & 0,064 \\
\hline
\end{tabular}

Sumber :Data diolah dengan SPSS 25 (2020)

Data pada Tabel 3 menunjukkan bahwa $\mathrm{N}=24$, artinya keputusan diambil dengan melihat data pada Shapiro-Wilk. Data dikatakan normal (simetris) dalam uji shapiro wilk jika nilai Sig. Lebih besar dari 0,05. Pada Tabel 3 menunjukkan bahwa Sig. Harga saham sebelum pengumuman kasus
COVID-19 untuk pertama kali di Indonesia (Sebelum) sebesar 0,592 sedangkan Sig. Harga saham sesudah pengumuman kasus COVID-19 untuk pertama kali di Indonesia (Sesudah) sebesar 0,064. Karena nilai sig. Lebih besar dari 0,05 maka dapat dikatakan data harga saham berdistribusi normal. 


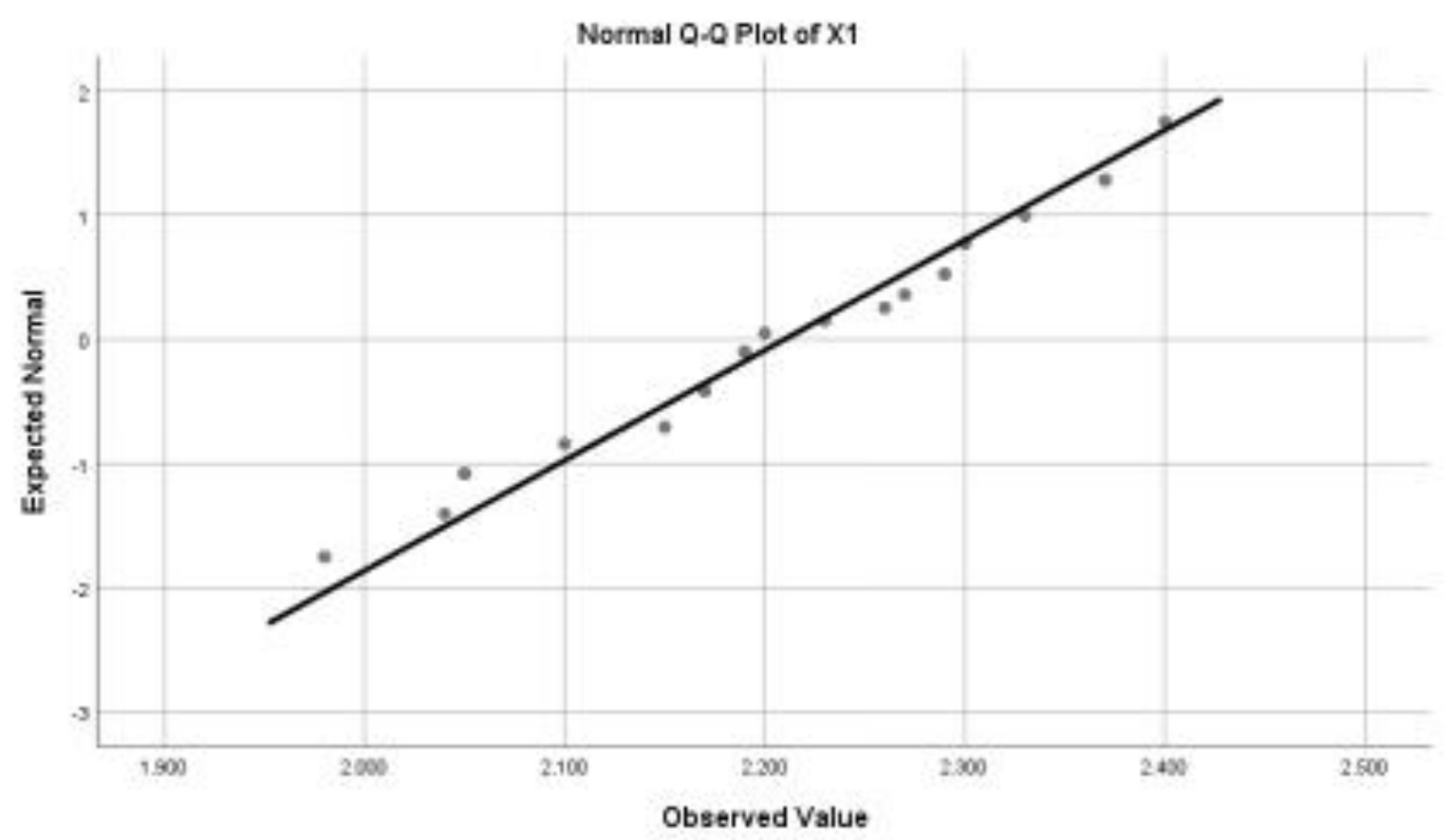

Gambar 1

Normal Q-Q Plot Harga Saham (Sebelum)

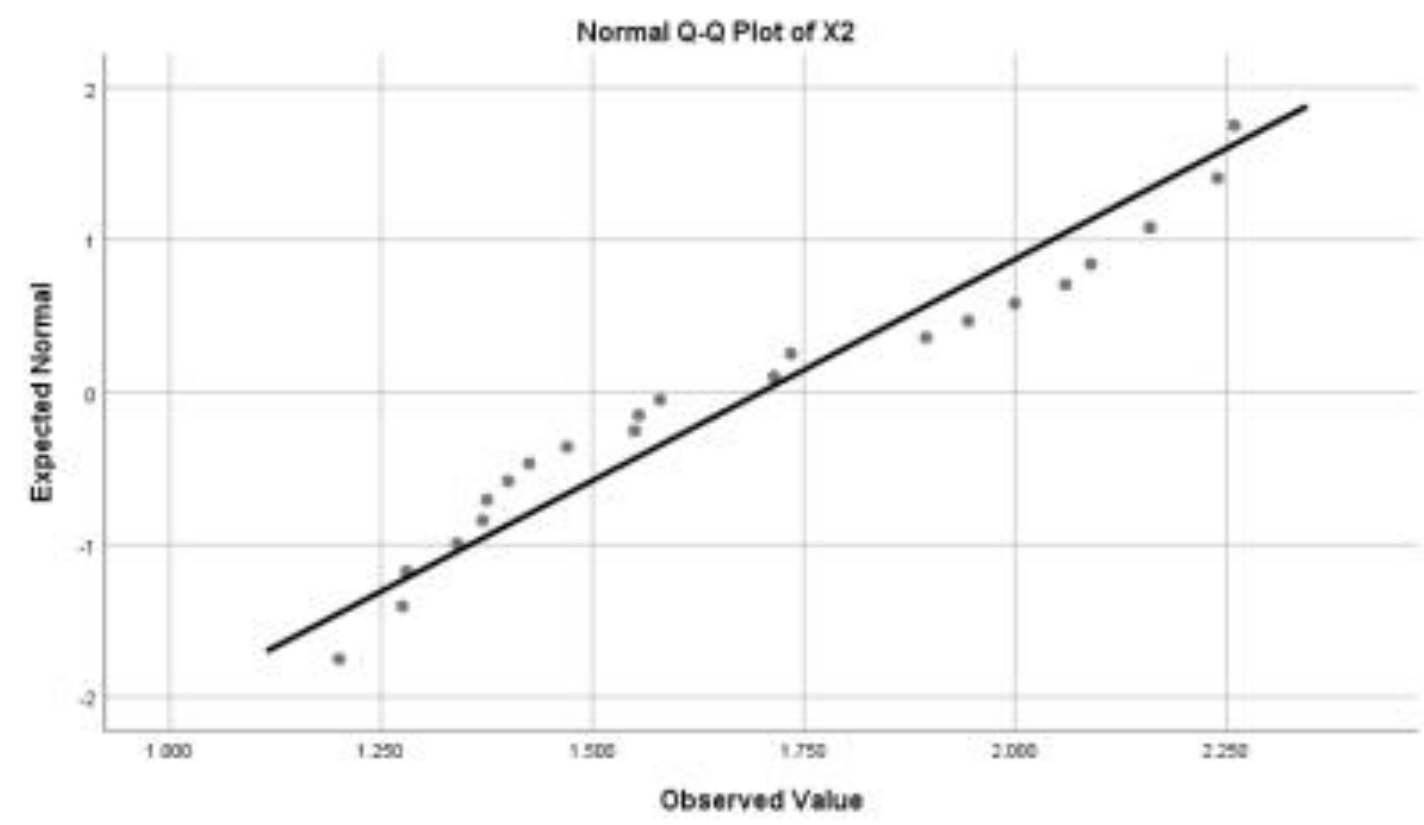

Gambar 2

Normal Q-Q Plot Harga Saham (Sesudah)

Secara teoritis, suatu set data dikatakan mempunyai sebaran normal apabila data tersebar di sekitar garis.

Gambar 1 dan Gambar 2 di atas terlihat bahwa data menyebar di sekitar garis.
Kesimpulannya dapat dikatakan bahwa kedua data harga saham baik sebelum maupun sesudah pengumuman kasus COVID-19 di Indonesia untuk pertama kali berdistribusi normal. 


\section{Return Saham}

Tabel 4

Uji Normalitas Return Saham

\begin{tabular}{lllllll}
\hline \hline & $\begin{array}{l}\text { Kolmogorov- } \\
\text { Smirnova }^{\mathbf{a}}\end{array}$ & & \multicolumn{3}{c}{$\begin{array}{l}\text { Shapiro- } \\
\text { Wilk }\end{array}$} \\
\hline Sebelum & Statistic & Df & Sig. & Statistic & Df & Sig. \\
Sesudah & 0,161 & 23 & 0,125 & 0,962 & 23 & 0,509 \\
& 0,195 & 23 & 0,024 & 0,914 & 23 & 0,051 \\
\hline
\end{tabular}

Sumber :Data diolah dengan SPSS 25 (2020)

Data pada Tabel 4 menunjukkan bahwa $\mathrm{N}=23$, artinya keputusan diambil dengan melihat data pada Shapiro-Wilk. Data dikatakan normal (simetris) dalam uji shapiro wilk jika nilai Sig. Lebih besar dari 0,05. Pada Tabel 4 menunjukkan bahwa Sig. return saham sebelum pengumuman kasus
COVID-19 untuk pertama kali di Indonesia (Sebelum) sebesar 0,509 sedangkan Sig. return saham sesudah pengumuman kasus COVID-19 untuk pertama kali di Indonesia (Sesudah) sebesar 0,051. Karena nilai sig. Lebih besar dari 0,05 maka dapat dikatakan data return saham berdistribusi normal.

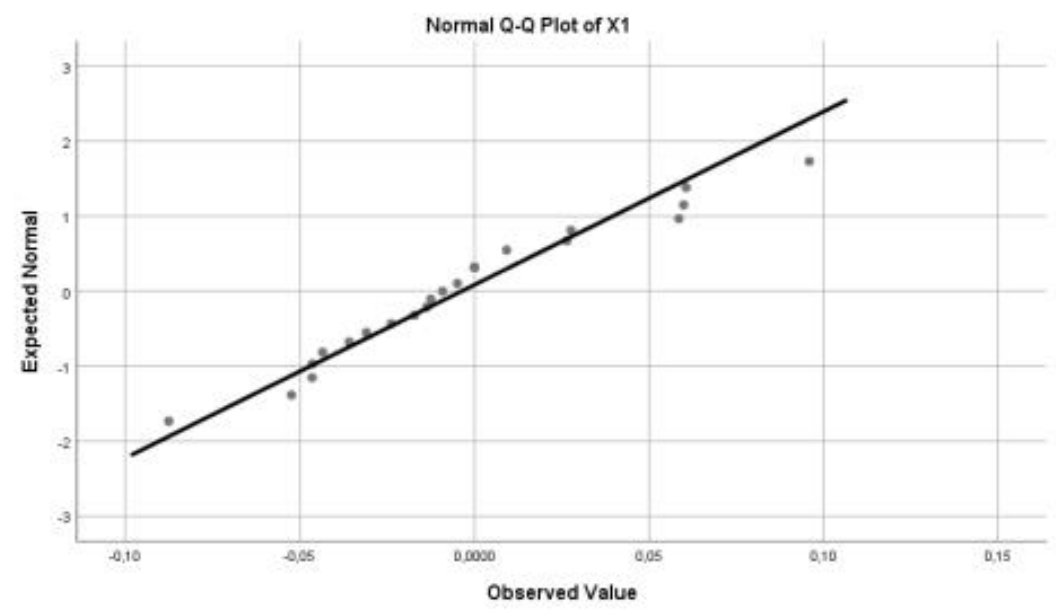

Gambar 3

Normal Q-Q Plot Return Saham (Sebelum)

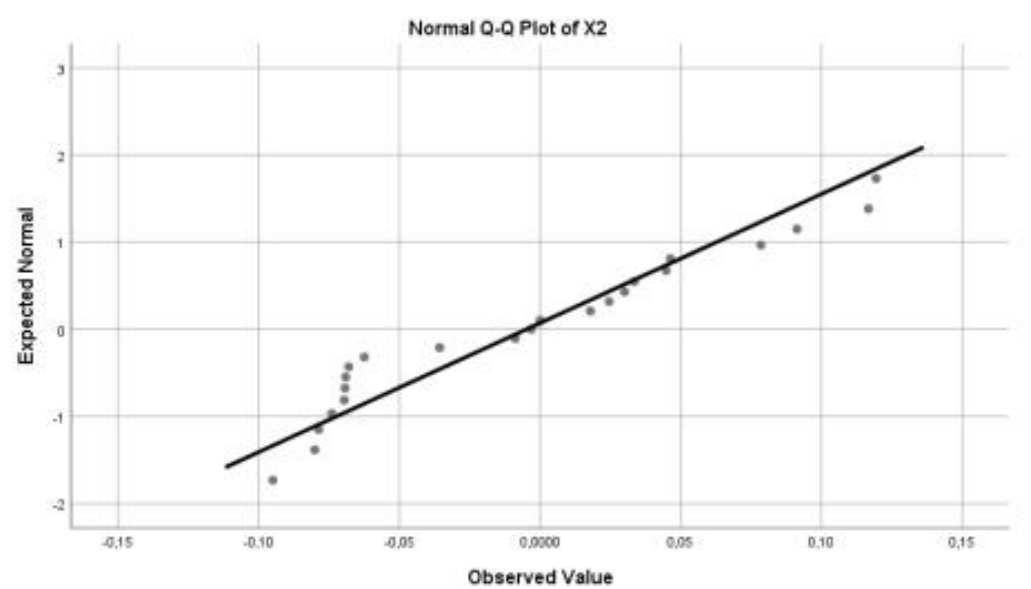

Gambar 4

Normal Q-Q Plot Return Saham (Sesudah) 
Secara teoritis, suatu set data dikatakan mempunyai sebaran normal apabila data tersebar di sekitar garis.

Gambar 3 dan Gambar 4 di atas terlihat bahwa data menyebar di sekitar garis.
Kesimpulannya dapat dikatakan bahwa kedua data return saham baik sebelum maupun sesudah pengumuman kasus COVID-19 di Indonesia untuk pertama kali berdistribusi normal.

\section{Hasil Uji Paired Sample T Test Harga Saham}

Tabel 5

Uji Paired Sample t Test Harga Saham

\begin{tabular}{|c|c|c|c|c|c|c|c|c|c|}
\hline & & \multirow[t]{2}{*}{ Mean } & \multirow[t]{2}{*}{$\begin{array}{l}\text { Std. } \\
\text { Deviation }\end{array}$} & \multirow[t]{2}{*}{$\begin{array}{l}\text { Std. } \\
\text { Error } \\
\text { Mean } \\
\end{array}$} & \multicolumn{2}{|c|}{$\begin{array}{l}\text { 95\% Confidence } \\
\text { Interval of the } \\
\text { Difference }\end{array}$} & \multirow[t]{2}{*}{$T$} & \multirow[t]{2}{*}{$d f$} & \multirow[t]{2}{*}{$\begin{array}{l}\text { Sig. (2- } \\
\text { tailed) }\end{array}$} \\
\hline & & & & & Lower & Upper & & & \\
\hline $\begin{array}{l}\text { Pair } \\
1\end{array}$ & $\begin{array}{l}\text { Sebelum - } \\
\text { Sesudah }\end{array}$ & 510,208 & 393,337 & 80,290 & 344,117 & 676,300 & 6,355 & 23 & 0,000 \\
\hline
\end{tabular}

Berdasarkan tabel 5 di atas, diketahui nilai Sig. (2-tailed) adalah sebesar 0,000. Tabel di atas juga memuat informasi tentang "Mean Paired Differences" adalah sebesar 510,208. Nilai ini menunjukkan selisih antara rata-rata harga saham sebelum dan sesudah pengumuman COVID19 pertama di Indonesia tanggal 2 Maret 2020 sebesar 510,208 dan selisih perbedaan tersebut antar 344,117 sampai dengan
676,300 (95\% Confidence Interval of the Difference Lower dan Upper).

Informasi dari tabel yang lain adalah diketahui t hitung sebesar 6,355 dan nilai df (degree of freedom atau derajad kebebasan) sebesar 23 dan nilai 0,05/2 sama dengan 0,025 , nilai ini akan menjadi acuan dalam mencari nilai $\mathrm{t}$ tabel pada distribusi nilai $\mathrm{t}$ tabel yang ditemukan nilai $\mathrm{t}$-tabel sebesar 2,089

\section{Return Saham}

Tabel 6

Uji Paired Sample t Test Return Saham

\begin{tabular}{|c|c|c|c|c|c|c|c|c|c|}
\hline & & \multirow[t]{2}{*}{ Mean } & \multirow[t]{2}{*}{$\begin{array}{l}\text { Std. } \\
\text { Deviation }\end{array}$} & \multirow[t]{2}{*}{$\begin{array}{l}\text { Std. } \\
\text { Error } \\
\text { Mean }\end{array}$} & \multicolumn{2}{|c|}{$\begin{array}{l}\text { 95\% Confidence } \\
\text { Interval of the } \\
\text { Difference }\end{array}$} & \multirow[t]{2}{*}{$T$} & \multirow[t]{2}{*}{$D f$} & \multirow[t]{2}{*}{$\begin{array}{l}\text { Sig. (2- } \\
\text { tailed) }\end{array}$} \\
\hline & & & & & Lower & Upper & & & \\
\hline $\begin{array}{l}\text { Pair } \\
1\end{array}$ & $\begin{array}{l}\text { Sebelum } \\
\text { - Sesudah }\end{array}$ & 0,00111 & 0,07766 & 0,01619 & $-0,03247$ & 0,03469 & 0,069 & 22 & 0,946 \\
\hline
\end{tabular}

Sumber :Data diolah dengan SPSS 25 (2020)

Berdasarkan Tabel 6 di atas, diketahui nilai Sig. (2-tailed) sebesar 0,946. Tabel di atas juga memuat informasi tentang "Mean Paired Differences" adalah sebesar 0,07766. Nilai ini menunjukkan selisih antara ratarata return saham sebelum dan sesudah pengumuman COVID-19 pertama di Indo- nesia tanggal 2 Maret 2020 sebesar 0,07766 dan selisih perbedaan tersebut antar 0,03247 sampai dengan 0,03469 (95\% Confidence Interval of the Difference Lower dan Upper). Informasi dari tabel yang lain adalah diketahui $\mathrm{t}$ hitung sebesar 0,069 dan nilai df (degree of freedom atau derajad 
kebebasan) sebesar 22 dan nilai 0,05/2 sama dengan 0,025 , nilai ini akan menjadi acuan dalam mencari nilai $t$ tabel pada distribusi nilai $t$ tabel sehingga ditemukan nilai t-tabel sebesar 2,074 .

\section{Pembahasan}

Perbedaan Harga Saham PT. Indosat, Tbk. Sebelum dan Sesudah diumumkannya Kasus Pertama COVID-19 di Indonesia.

Dari hasil Uji Paired t-Test yang telah dilakukan terhadap harga saham PT. Indosat, Tbk. sebelum dan sesudah diumumkannya kasus pertama COVID-19 di Indonesia dengan menggunakan SPSS 25 diperoleh nilai sig. $0,000<0,05$ dan juga nilai t-hitung 6,355 > t-tabel 2,089.

Berdasarkan hasil tersebut, dapat dikatakan bahwa koefisien harga Saham signifikan maka $\mathrm{H}_{1}$ diterima. Sehingga terdapat perbedaan yang signifikan secara parsial antara Harga Saham PT. Indosat, Tbk. sebelum dan sesudah diumumkannya kasus pertama COVID-19 di Indonesia. Hal ini bisa terjadi dikarenakan dalam kenyataannya investor tidak senantiasa rasional. Investor mungkin bereaksi berlebihan dalam jangka pendek ketika mereka pesimis atau terlalu mementingkan peristiwaperistiwa baru-baru ini dan mengabaikan data historis (Ding et al., 2020). Hal ini menyebabkan penurunan tajam harga saham karena berita yang merugikan yang menyebabkan investor mungkin pesimis dikarenakan jumlah kasus positif COVID-19 terus meningkat dan resiko kematiannya pun besar.

Hasil dari penelitian lain juga menemukan bahwa investor melakukan reaksi berlebihan terhadap bencana skala besar yang belum pernah terjadi sebelum- nya seperti teroris ataupun gempa (Cam dan Ramiah, 2012; Lee et al., 2018). COVID-19 pun merupakan kondisi pandemic yang luarbiasa dan belum pernah ditemukan virus ini sebelumnya terlebih belum ada vaksin, sehingga bisa mengakibatkan reaksi berlebihan para investor yang berakibat pada harga saham. Hasil penelitian (Ashraf,
2020) menunjukkan bahwa pasar saham merespon secara negatif peningkatan kasus terkonfirmasi COVID-19.

Artinya, ketika jumlah kasus COVID-19 meningkat di suatu negara, maka hasil pasar saham menurun. Hal ini juga dikonfirmasi oleh penelitian Ding et al. (2020) yang menyatakan bahwa pada kondisi pandemic akan membuat pasar menjadi sentiment sehingga berpengaruh signifikan terhadap harga saham. Hasil Penelitian Ini sejalan dengan penelitian yang dilakukan oleh Nurmasari (2020), Fanni (2012), dan Seto dan Septianti (2019), bahwa terdapat perbedaan harga saham yang signifikan sebelum dan sesudah peristiwa-peristiwa baik peristiwa ekonomi maupun non-ekonomi yang ditunjukkan dengan perubahan harga saham. Pandemi COVID-19 baru-baru ini juga membangunkan ketidakpercayaan pada masyarakat (Mazumder, 2020).

Perbedaan Return Saham PT. Indosat, Tbk. Sebelum dan Sesudah Diumumkannya Kasus Pertama COVID-19 di Indonesia.

Dari hasil Uji Paired t-Test yang telah dilakukan terhadap return saham PT. Indosat,Tbk. sebelum dan sesudah diumumkannya kasus pertama COVID-19 di Indonesia dengan menggunakan SPSS 25 diperoleh nilai sig. 0,946>0,05 dan juga nilai t-hitung $0,069<\mathrm{t}$-tabel 2.074 .

Berdasarkan hasil tersebut, maka $\mathrm{H}_{2}$ ditolak. Sehingga dapat disimpulkan bahwa tidak terdapat perbedaan yang signifikan secara parsial antara return saham PT. Indosat, Tbk. sebelum dan sesudah diumumkannya kasus pertama COVID-19 di Indonesia. Hasil Penelitian ini tidak sejalan dengan penelitian yang dilakukan oleh Ashraf (2020), Thomas et al. (2020), dan Manurung (2019), bahwa terdapat perbedaan return saham yang sebelum dan sesudah peristiwa-peristiwa baik peristiwa ekonomi maupun non-ekonomi yang ditunjukkan dengan perubahan return saham. 


\section{SIMPULAN DAN SARAN \\ Simpulan}

Berdasarkan pada data yang telah dikumpulkan dan pengujian yang telah dilakukan, maka bisa disimpulkan bahwa terdapat perbedaan harga saham PT Indosat, Tbk sebelum dan sesudah diumumkannya kasus pertama COVID-19 di Indonesia dan tidak terdapat perbedaan return saham PT Indosat, Tbk sebelum dan Sesudah diumumkannya kasus pertama COVID-19 di Indonesia. Harga saham mengalami penurunan dikarenakan perekonomian yang tidak menentu akibat adanya pandemic covid-19. Covid 19 pun merupakan kondisi pandemic yang luarbiasa dan belum pernah ditemukan virus ini sebelumnya terlebih belum ada vaksin, sehingga bisa mengakibatkan reaksi berlebihan para investor yang berakibat pada harga saham. Ketika jumlah kasus COVID-19 meningkat di suatu negara, maka hasil pasar saham menurun. Artinya bahwa pada kondisi pandemic seperti ini akan membuat pasar menjadi sentiment sehingga berpengaruh signifikan terhadap harga saham sehingga perbedaan harga saham yang signifikan sebelum dan sesudah peristiwa-peristiwa baik peristiwa ekonomi maupun non-ekonomi yang ditunjukkan dengan perubahan harga saham. pandemi COVID-19 barubaru ini juga membangunkan ketidak percayaan pada masyarakat (Mazumder, 2020).

Berdasarkan pada data yang telah dikumpulkan dan pengujian yang telah dilakukan, maka dapat diambil beberapa simpulan, yaitu:

1. Terdapat perbedaan Harga Saham PT. Indosat, Tbk. sebelum dan sesudah diumumkannya kasus pertama covid-19 di Indonesia.

2. Tidak terdapat perbedaan Return Saham PT. Indosat, Tbk. sebelum dan sesudah diumumkannya kasus pertama covid-19 di Indonesia.

\section{Saran}

Saran untuk PT. Indosat, Tbk yakni:
1. Bagi perusahaan PT. Indosat, Tbk. Diharapkan dapat berupaya menjaga kestabilan kenaikan harga saham guna menjaga kepercayaan dan ketertarikan investor dan masyarakat karena nilai harga saham yang stabil atau terus meningkat dapat meningkatkan return saham

2. Harga saham dipengaruhi oleh permintaan dan penawaran ats jasa atau produk yang diperjual belikan perusahaan, sehingga PT. Indosat dapat memaksimalkan pembelian produk secara online dengan memberi promosi-promosi khusus atas pembelian secara online seperti melalui marketplace dan $\mathrm{m}$ banking.

3. Pasar Saham merupakan salah satu dari bagian makroekonomi karena cakupannya yang besar. Dari pasar saham Investor dapat menilai prospek perusahaan sehingga dapat menentukan minat investor dalam penanaman saham pada perusahaan. Hal ini dapat dijadikan sebagai salah satu strategi perusahaan dalam melakukan persaingan usaha dalam tujuan memperoleh modal yang dibutuhkan sehingga dapat membantu meningkatkan kinerja perusahaan dimana dalam peristiwa pandemi ini dibuthkan banyak modal akan tetapi para investor sangat berhati-hati di masa yang tidak terduga seperti ini.

\section{Keterbatasan}

1. Keterbatasan dari penelitian ini memberikan peluang bagi penelitian selanjutnya yakni diharapkan penelitian di masa depan dapat menambah variabel baru seperti abnormal return dan volume transaksi saham mengingat dalam penelitian ini belum dibahas.

2. Di penelitian ini hanya membahas PT Indosat, Tbk, penelitian selanjutnya bisa menambah jumlah perusahaan yang diteliti agar penelitian semakin luas Selain itu penelitian ini sangat mungkin menjadi penelitian eksplanatory research, 
yang memiliki variabel dependen dan variabel independen.

\section{DAFTAR PUSTAKA}

Al-Awadhi, A. M., K. Alsaifi, A. Al-Awadhi dan S. Alhammadi. 2020. Death and contagious infectious diseases: Impact of the COVID-19 virus on stock market returns. Journal of Behavioral and Experimental Finance 27: 100326. https: //doi.org/10.1016/j.jbef.2020.100326

Alex, D. dan N. Latheef. 2017. Accounting Information, Dividend Announcement and Ex-Dividend Effects on Stock Returns-Evidence from Indian Market. SSRG International Journal of Economics and Management Studies 4(1): 1-9.

Antono, Z., A. Jaharadak, dan A. Khatibi. 2019. Analysis of factors affecting stock prices in mining sector: Evidence from Indonesia Stock Exchange. Management Science Letters 9(10): 1701-1710.

Apergis, N. dan E. Apergis. 2020. The role of COVID-19 for Chinese stock returns: evidence from a GARCHX model. AsiaPacific Journal of Accounting and Economics 00(00): 1-9. https://doi.org/ 10.1080/16081625.2020.1816185

Arista, D. dan A. Astohar. 2012. Analisis Faktor-Faktor Yang Mempengaruhi Return Saham. Jurnal Ilmu Manajemen Dan Akuntansi Terapan (JIMAT) 3(1).

Ashraf, B. N. 2020. Stock markets' reaction to COVID-19: Cases or fatalities? Research in International Business and Finance 54: 101249. https://doi.org/ 10.1016/j.ribaf.2020.101249

Bouslah, K., L. Kryzanowski, dan B. M'Zali. 2018. Social performance and firm risk: Impact of the financial crisis. Journal of Business Ethics 149: 643-669. https:// doi.org/10.1007/s10551-016-3017-x

Bozhkov, S., H. Lee, U. Sivarajah, S. Despoudi, dan M. Nandy. 2018. Idiosyncratic risk and the crosssection of stock returns: The role of meanreverting idiosyncratic volatility. Annals of Operations Research: 1-34. https://doi.org/10.1007/s10479-0182846-7

Branzei, O., T. J. Ursacki-Bryant, I. Vertinsky, dan W. Zhang. 2004. The formation of green strategies in Chinese firms: Matching corporate environmental responses and individual principles. Strategic Management Journal, 25(11): 1075-1095.

Budiarso, N. S., A. W. Hasyim, R. Soleman, I. Z. Zam, dan W. Pontoh. Investor Behavior Under The Covid-19 Pandemic: The Case Of Indonesia. Innovations 17(3): 308-318.

Bursa Efek Indonesia. (n.d.). No Title.

Cam, M.-A. dan V. Ramiah. 2012. The influence of systematic risk factors and econometric adjustments in catastrophic event studies. Review of Quantitative Finance and Accounting 42(2): 171189. http://www.oarsijournal.com/ article/ S1063-4584(05)80703-4/pdf

Carter, S. M. 2006. The interaction of top management group, stakeholder, and situational factors on certain corporate reputation management activities. Journal of Management Studies 43(5): 1145-1176.

Connelly, B. L., S. T. Certo, R. D. Ireland, dan C. R. Reutzel. 2011. Signaling theory: A review and assessment. Journal of management 37(1): 39-67.

Ding, D., C. Guan, C. M. L. Chan, dan W. Liu. 2020. Building stock market resilience through digital transformation: using Google trends to analyze the impact of COVID-19 pandemic. Frontiers of Business Research in China 14(1). https://doi.org/10.1186/s11782020-00089-z

Fama, E. 1970. Efficient capital markets: A review of theory and empirical work. The Journal of Finance 25(2): 383-417. https:/ / doi.org/10.2307/2325486

Fama, E. 1998. Market efficiency, long-term returns, and behavioral finance. Journal of Financial Economics 49(3): 283-306.

Fanni, C. M. 2012. Reaksi Pasar Modal Terhadap Bencana Banjir Jakarta Tahun 
2013 (Event Study Pada Saham Perusahaan Asuransi Yang Listing Di BEI). Jurnal Ilmiah Mahasiswa FEB 1(2).

Gulati, R. dan M. C. Higgins. 2003. Which ties matter when? The contingent effects of interorganizational partnerships on IPO success. Strategic Management Journal 24(2): 127-144.

Hasibuan, G. L., D. Dermawan, H. S. Ginting, dan I. Muda. 2020. Allocation of COVID-19 Epidemic Funding Budgets in Indonesia. International Journal of Research and Review 7(5): 75-80.

He, P., Y. Sun, Y. Zhang, dan T. Li. 2020. COVID-19's Impact on Stock Prices Across Different Sectors-An Event Study Based on the Chinese Stock Market. Emerging Markets Finance and Trade 56(10): 2198-2212. https://doi. org/10.1080/1540496X.2020.1785865

Hidayaturrahman, M. dan E. Purwanto. 2020. COVID-19: Public support to handle economic challenges. Jurnal Inovasi Ekonomi 5(2).

Ikriyah, N., A. W. Mahsuni, dan M. C. Mawardi. 2017. Analisis Dampak Akuisisi Terhadap Harga Saham Perusahaan Pengakuisisi PT. Pp Properti Tbk. Pada PT. Wisma Seratus Sejahtera Tahun 2016. Jurnal Ilmiah Riset Akuntansi 6(08).

Jogiyanto, H. 2010. Teori portofolio dan analisis investasi (edisi ketujuh). BPFE. Yogyakarta.

Joshi, S. S. 2017. Effect of Dividend Announcement On Stock Prices of Indian Companies: A Study of Nifty Index. Asia Pacific Journal of Research In Business Management 8(6).

Kasmir. 2014. Bank dan Lembaga Keuangan Lainnya (Revisi 2014). PT RajaGrafindo Persada. Jakarta.

Khan, K., H. Zhao, H. Zhang, H. Yang, M. H. Shah dan A. Jahanger. 2020. The impact of COVID-19 pandemic on stock markets: An empirical analysis of world major stock indices. Journal of Asian Finance, Economics and Business 7(7): 463-474. https:// doi.org/10.13106/jafeb.2020.vo 17.no7.463

Lahmiri, S. dan S. Bekiros. 2020. The impact of COVID-19 pandemic upon stability and sequential irregularity of equity and cryptocurrency markets. Chaos, Solitons dan Fractals 138 (September): 109936.

Lee, D. dan R. Faff. 2009. Corporate sustainability performance and idiosyncratic risk: A global perspective. The Financial Review 44(2): 213-237. https: / / doi.org/10.1111/j.15406288.2009.002 16.x

Lee, K.-J., S.-L. Lu dan Y. Shih. 2018. Contagion Effect of Natural Disaster and Financial Crisis Events on International Stock Markets. Journal of Risk and Financial Management 11(2): 16. https://doi.org/10.3390/jrfm11020016

Liu, B. dan A. Di Iorio. 2016. The pricing of idiosyncratic volatility: An Australian study. Australian Journal of Management 41(2): 353-375. https://doi.org/10. $1177 / 0312896214541554$

Mahammed, M. A. 2020. Analysis of Covid19 Lockdown Policy Impact By The Government of The Country On The Economic Sector And Signing of Working Relationships (Layoffs). International Journal of Law Reconstruction 4(1): 44-54.

Majanga, B. 2015. The dividend effect on stock price-An empirical analysis of Malawi listed companies. Accounting and Finance Research 4(3).

Manurung, H. 2019. Pengaruh Pemilu Serentak Terhadap Return Saham di Indonesia (Studi Kasus Saham Lq-45 Di Bursa Efek Indonesia). Journal for Business and Entrepreneurship 3(1).

Markowitz, H. 1952. Portfolio selection. The Journal of Finance 7(1): 77-91. https:// doi.org/10.2307/2975974

Mazumder, S. 2020. How important is social trust during the COVID-19 crisis period? Evidence from the Fed announcements. Journal of Behavioral and Experimental Finance 28: 100387. 
https://doi.org/10.1016/j.jbef.2020.100 387

Mazur, M., M. Dang, dan M. Vega. 2020. COVID-19 and the march 2020 stock market crash. Evidence from S\&P1500. Finance Research Letters July: 101690. https://doi.org/10.1016/j.frl.2020.1016 90

Novitasari, I., D. Budiadi, dan A. D. Limantara. 2020. Analisis Stock Split Terhadap Harga Saham PT Jaya Real Property Tahun 2010-2016. CAHAYA AKTIVA 10(1): 9-18.

Nurhidayat, D. 2020. Terimbas Pandemi COVID-19, Perdagangan Bursa Terus Menurun. https://mediaindonesia.com/ read/detail/307210-terimbas-pandemiCOVID-19-perdagangan-bursa-terusmenurun.

Nurmasari, I. 2020. Dampak COVID-19 Terhadap Perubahan Harga Saham dan Volume Transaksi (Studi Kasus Pada PT. Ramayana Lestari Sentosa, Tbk.). Jurnal SEKURITAS (Saham, Ekonomi, Keuangan Dan Investasi) 3(3): 230-236.

OuYang, Z., J. Xu, J. Wei, dan Y. Liu. 2017. Information asymmetry and investor reaction to corporate crisis: Media reputation as a stock market signal. Journal of Media Economics 30(2): 82-95. http://dx.doi.org/10.1080/08997764.20 17.1364256

Perkins, S. J. dan C. Hendry. 2005. Ordering top pay: Interpreting the signals. Journal of Management Studies 42: 1443-1468.

Ross, S. 1977. The determination of financial structure: The incentive-signalling approach. The Bell Journal of Economics 8(1): 23-40. https://doi.org/10.2307/ 3003485

Salisu, A. A. dan L. O. Akanni. 2020. Constructing a Global Fear Index for the COVID-19 Pandemic. Emerging Markets Finance and Trade 56(10): 23102331. https:/ / doi.org/10.1080/1540496X.202 0.1785424

Shehzad, K., L. Xiaoxing, dan H. Kazouz. 2020. COVID-19's disasters are perilous than Global Financial Crisis: A rumor or fact? Finance Research Letters 36: 101669. https://doi.org/10.1016/j.frl. 2020.101669

Shubiri, F. dan S. Jamil. 2018.The impact of idiosyncratic risk of banking sector on oil, stock market, and fiscal indicators of Sultanate of Oman. International Journal of Engineering Business Management 10: 1-8. https://doi.org/10. $1177 / 1847979017749043$

Seto, A. A. dan D. Septianti. 2019. Dampak Kenaikan Harga Tiket Pesawat Terhadap Return dan Harga Saham pada PT. Garuda Indonesia Tbk di Bursa Efek Indonesia. Jurnal Ilmiah Ekonomi Global Masa Kini 10(1): 1-7.

Spence, M. 1978. Job market signaling. In Uncertainty in economics. The Quarterly Journal of Economics 87(3): 355-374.

Sugiyono. 2019. Metode Penelitian Kuantitatif Kualitatif dan R\&D. Penerbit Alfabeta. Bandung.

Thomas, T. C., G. Sankararaman, dan S. Suresh. 2020. Impact of Covid-19 Announcements On Nifty Stocks. Journal Of Critical Reviews 7(13): 471-475.

Undang-Undang nomor 8 tahun 1995 tentang Pasar Modal.

Wibowo, A. dan S. Darmanto. 2019. Impact of Quick Count Result of President Election on Stock Prices and Trade Activities in the Indonesian Capital Market. Saudi Journal of Business and Management Studies 4(6): 487-493. 